\title{
Evaluation of quality characteristics of Korean and Chinese buckwheats
}

\author{
MyoungLae Cho ${ }^{1}$, Sun-il Choi ${ }^{1}$, Jin-Ha Lee ${ }^{1}$, Bong-Jae Cho ${ }^{2}$, Hyo-ku Lee ${ }^{2}$, \\ Seong-Kap Rhee ${ }^{3}$, Jeong-Ho $\mathrm{Lim}^{4}$, Ok-Hwan Lee ${ }^{1 *}$ \\ ${ }^{1}$ Department of Food Science and Biotechnology, Kangwon National University, Chuncheon 24341, Korea \\ ${ }^{2}$ Department of Food Science, Kongju National University, Yesan 32439, Korea \\ ${ }^{3}$ Reseat/Korea Institute of Science and Technology Information, Daejeon 34141, Korea \\ ${ }^{4}$ Korea Food Research institute, Seongnam 13539, Korea
}

\section{품종에 따른 국내산 및 중국산 메밀의 품질특성}

\author{
조명래 ${ }^{1} \cdot$ 최선일 $^{1} \cdot$ 이진하 $^{1} \cdot$ 조봉제 ${ }^{2} \cdot$ 이효구 $^{2} \cdot$ 이성갑 $^{3} \cdot$ 임정호 $^{4} \cdot$ 이옥환 ${ }^{1 *}$ \\ ${ }^{1}$ 강원대학교 식품생명공학과, ${ }^{2}$ 공주대학교 식품공학과, \\ ${ }^{3}$ 한국과학기술정보연구원, ${ }^{4}$ 한국식품연구원
}

\begin{abstract}
This study investigated the quality characteristics (chemical composition, amino acid content, lipid content, and rutin content) of common and tartary buckwheats cultivated from Korea and China. The moisture, crude protein, crude fat, crude ash, and carbohydrate contents of various common and tartary buckwheats were 8.78 13.37\%, $11.00 \sim 12.11 \%$, 2.87 3.18\%, $1.80 \sim 2.58 \%$, and 70.2 $73.8 \%$, respectively. The major amino acids in Korean and Chinese buckwheats were aspartic acid $(1,105.1 \sim 1,403.5 \mathrm{mg} / 100$ g), glutamine $(2,250.9 \sim 2,996.1 \mathrm{mg} / 100 \mathrm{~g})$, and arginine $(932.5 \sim 1,388.6 \mathrm{mg} / 100 \mathrm{~g})$. The major minerals were $\mathrm{K}(423.7 \sim 569.4 \mathrm{mg} / 100 \mathrm{~g}), \mathrm{Mg}(181.8 \sim 255.9 \mathrm{mg} / 100 \mathrm{~g})$, and $P(328.6 \sim 555.0 \mathrm{mg} / 100 \mathrm{~g})$. Palmitic acid (14.2 16.1\%) was the major saturated fatty acid, and oleic (37.0 40.8\%) and linoleic $(31.7 \sim 38.6 \%)$ acids were the major unsaturated fatty acids. Tartary buckwheats $(261.0 \sim 265.0 \mathrm{mg} / \mathrm{g})$ had significantly higher rutin contents than that of common buckwheats $(4.39 \sim 5.68 \mathrm{mg} / \mathrm{g})$. These results suggested that common and tartary buckwheats cultivated in Korea and China contain naturally occumingnutrients in an abundance.
\end{abstract}

Key words : tartary buckwheats, common buckwheats, quality characteristics, Korean, Chinese

\section{서 론}

메밀은 전 세계적으로 재배되고 있는 작물로서, 미네랄, 비타민, 폴리페놀(루틴 등) 등이 풍부하고, 다양한 생리활성 을 갖기 때문에 오래 전부터 많은 연구가 되고 있다 $(1,2)$. 특히 메밀에 함유된 폴리페놀 성분인 루틴은 항산화(3), 항염증(4), 항암(5) 효과 이외에도 혈관손상 예방(6), 인지기

*Corresponding author. E-mail : loh99@kangwon.ac.kr Phone : 82-33-250-6454, Fax : 82-33-259-5565

Received 22 July 2015; Revised 24 February 2016; Accepted 2 March 2016.

Copyright (c) The Korean Society of Food Preservation. All rights reserved.
능 개선(7) 등의 생리 기능성을 갖고 있다. 메밀은 품종에 따라 단메밀(common buckwheat)과 쓴메밀(tatary buckwheat) 로 나뉘며 두 종류 모두 곡실용, 의약용 등의 농업 및 산업적 으로 이용되고 있다. 단메밀은 아시아를 포함한 유럽, 미국, 캐나다, 브라질, 남아프리카와 오스트리아 등지에서 주로 재배되고 있으며, 쓴메밀은 티벳이나 중국의 산악지대, 인 도, 부탄과 네팔 등지의 척박한 토양 및 냉량한 기후조건의 산간지역에서 재배되며, 타타리 메밀이라고도 불려지고 있 다(2). 현재 국내에서는 쓴메밀의 재배가 거의 이루어지지 않고 있지만 중국, 인도 등지에서 쓴메밀은 한방 및 건강식 으로 이용되어 왔고 단메밀에 비해 루틴 등의 페놀화합물 함량이 높기 때문에 다양한 연구가 시도되고 있다. Yoon 등(8)의 연구에 의하면 중국산 쓴메밀 추출물은 국내산 단 
메밀 추출물 보다 항산화 활성 및 지방세포 분화효과가 높은 것으로 보고되었으며, Tsai 등(9)은 타이산 단메밀과 쓴메밀 추출물이 높은 항산화 활성 및 angiotensin-coverting enzyme(ACE) 억제효과를 보인다고 하였다. 한편, Bonafaccia 등(10)은 슬로바니아산 단메밀과 쓴메밀에 함유된 미네랄 함량을 분석하였는데, 단메밀과 쓴메밀에 함유된 selenium, nikel은 크게 차이를 보이지 않았지만, zink, iron, cobalt는 단메밀보다 쓴메밀에 많이 함유되어 있었다고 보고하였다. 그러나, 아직까지 한국 및 중국 등의 아시아 지역에서 수확 되는 단메밀과 쓴메밀의 일반성분 차이, 생리 기능성 차이 등에 관한 구체적인 연구는 거의 수행되지 않고 있다.

최근, 중국과의 자유무역협정으로 인하여 국내산 농산물 의 보호를 위한 노력이 요구되고 있는 실정에서 국내산 메밀(단메밀, 쓴메밀)과 중국산 메밀의 품질특성 연구는 향후 국내산 메밀의 활용도를 높이는 차원에서 매우 필요한 연구로 사료된다. 따라서 본 연구에서는 국내산 및 중국산 단메밀과 쓴메밀의 식품학적 기초자료를 제공하고자 일반 성분, 아미노산 조성, 미네랄 함량, 지방산 조성 등을 분석하 였다. 또한, 국내산 및 중국산 단메밀과 쓴메밀의 루틴함량 을 HPLC를 이용하여 분석하였다.

\section{재료 및 방법}

\section{실험 재료 및 시약}

본 연구에서 사용된 국내산 단메밀 및 쓴메밀은 농촌진 흥청 고랭지시험장에서 제공받았으며, 중국산 단메밀 및 쓴메밀은 동아제분(주)에서 제공받아 사용하였다.

품종별 메밀시료는 이물질을 제거하고 20 30 mesh로 조분쇄 한 후, 일반성분, 아미노산, 유리당, 지방산, 무기질 등의 식품학적 성분분석 및 루틴 함량 분석에 사용하였다. 실험에 사용한 시약은 분석용으로 Sigma(Sigma-Aldrich Co., St. Louis, MO, USA)로부터 구입하여 사용하였다.

\section{일반성분 분석}

각 메밀에 함유된 수분, 조회분, 조단백질, 조지방 함량은 Association of Official Agricultural Chemists(AOAC)(11)의 방법에 따라 분석하였다. 수분은 $105^{\circ} \mathrm{C}$ 상압건조법으로 분 석하였으며, 조지방은 soxhlet을 이용하여 추출 후 분석하 였다. 조단백은 Kjeldahl법을 적용한 분석기기인 semi-micro kjeldahl법을 이용하였으며, 조회분은 $550^{\circ} \mathrm{C}$ 회 화로에서 6시간 가열하여 얻은 회화의 양을 측정하였다. 탄수화물 함량은 전체 시료 $100 \%$ 에서 수분, 조회분, 조단 백질, 조지방의 합한 값을 100 에서 뺀 값으로 하였다.

\section{아미노산 분석}

아미노산 함량 분석은 Waters에서 제조한 AccQ-Tag(12)
의 방법을 이용하여 분석하였다. 분말시료 약 $0.2 \mathrm{~g}$ 을 정확 히 취하여 $50 \mathrm{~mL}$ 앰플에 넣고 $6 \mathrm{~N} \mathrm{HCl} 15 \mathrm{~mL}$ 를 가한 다음 $\mathrm{N}_{2}$ 로 치환하여 신속하게 밀봉하였다. 이를 $110^{\circ} \mathrm{C}$ 오븐 에서 24시간 가수분해 시킨 뒤 방냉하고, $50 \mathrm{~mL}$ 정용플라스 크에 옮겨 탈이온수로 정용하였다. 그 후, $0.2 \mu \mathrm{m}$ membrane 필터로 여과하고, AccQ-Fluor Reagent Kit(WAT052880, Waters, Milford, MA, USA)를 이용하여 유도체화 시켜 구성 아미노산을 분석하였다. 즉, 여과된 유리 아미노산 시료 $10 \mu \mathrm{L}$ 를 시험관 $(\Phi 6 \times 50 \mathrm{~mm})$ 밑바닥에 취하고 여기에 AccQ-Fluor Reagent Kit의 1 용액 $70 \mu \mathrm{L}$ 를 넣어 혼합하였다. 그 후, 혼합액에 미리 $55^{\circ} \mathrm{C}$ 에서 반응시킨 2 용액 $20 \mu \mathrm{L}$ 를 넣어 혼합하였고, 이를 실온에서 1 분간 방치한 후 $55^{\circ} \mathrm{C}$ 에서 10 분간 유도체화시킨 다음 HPLC로 유리 아미노산을 측정 하였다. 분석에 사용한 아미노산 표준물질은 amino acid standard H(Pierce, Waltham, MA, USA)이고, 칼럼은 AccQ-Tag column $(3.9 \times 150 \mathrm{~mm}$, Waters, Milford, MA, $\mathrm{USA})$, 검출기는 fluorescence $(\mathrm{Ex}=250 \mathrm{~nm}, \mathrm{Em}=395 \mathrm{~nm}$, Jasco, Tokyo, Japan)를 사용하였으며, 분석온도는 $37^{\circ} \mathrm{C}$ 이었 다.

\section{지방산 분석}

지방산 분석은 gas chromatography $(\mathrm{GC})$ 를 이용하여 측정 하였다. 지방질은 soxhlet 추출법을 이용하였으며, $\mathrm{AOAC}(13)$ 법에 따라 $50 \mathrm{~mL}$ 의 둥근플라스크에 지방질 $200 \mathrm{mg}$ 을 취하 여 $0.5 \mathrm{~N} \mathrm{NaOH} / \mathrm{MeOH}$ 를 넣고 환류냉각기를 부착한 다음 지방구가 없어질 때까지 가열된 모래상자에서 5-10분간 가수분해 시켰다. $10 \% \mathrm{BF}_{3} / \mathrm{MeOH} 5 \mathrm{~mL}$ 을 환류냉각기 위로 천천히 넣어 2 분간 모래상자에 방치하여 반응시켰다. 다시 $5 \mathrm{~mL}$ hexane을 환류냉각기 위로 넣어 1분간 반응시키고, 냉각관에서 분리하여 반응플라스크에 포화식염수 $15 \mathrm{~mL}$ 을 넣고 마개를 막은 상태에서 5 초간 가볍게 흔들어 준 후 포화 식염수를 추가로 넣어 hexane층이 플라스크 목까지 올라오도록 하였다. Hexane층을 뽑아 무수황산나트륨이 들어있는 파스퇴르 피펫을 통과시켜 탈수시키고 탈수된 시험액을 $\mathrm{GC}$ 에 주입하여 분석하였다. 사용한 칼럼은 HP-INNO Wax(30 m×0.25 mm×0.25 $\mu \mathrm{m}$ film thickness), 검 출기는 불꽃이온화 검출기, 주입기 온도는 $220^{\circ} \mathrm{C}$, 검출기 온도는 $275^{\circ} \mathrm{C}$, 오븐의 온도는 $50^{\circ} \mathrm{C} / 3 \mathrm{~min}-10^{\circ} \mathrm{C} / \mathrm{min}-250^{\circ} \mathrm{C} / 5$ $\min$, 운반기체는 헬륨이었다.

\section{무기질 분석}

무기질 분석은 유도결합 프라즈마 원자방출 분광법을 이용하여 측정하였다. 무기질의 전처리 방법은 $\mathrm{AOAC}$ 에 의한 건식법(14)으로 하였다. 즉, 시료 약 $2 \mathrm{~g}$ 을 도가니에 넣고 전열기에서 예비 가열시킨 후 $550^{\circ} \mathrm{C}$ 전기 회화로에서 6 시간 회화한 다음 방냉하였다. 여기에 탈이온수 10 방울을 가하고 묽은질산(1:1, $\left.\mathrm{HNO}_{3}\right) 4 \mathrm{~mL}$ 를 넣은 다음 다시 전열기 
$\left(120^{\circ} \mathrm{C}\right)$ 에서 수분을 제거시키고 $550^{\circ} \mathrm{C}$ 전기 회화로에서 1 시 간 회화 및 방냉하였다. 그 후, 묽은염산 $(1: 1, \mathrm{HCl}) 10 \mathrm{~mL}$ 를 첨가하고 이를 $50 \mathrm{~mL}$ 정용플라스크로 옮겨 탈이온수로 정용, 여과하여 유도결합 프라즈마 원자방출 분광법 (ICP-AES, Inductively Coupled Plasma Atomic Emission Spectrophotometer, Jobin Yvon JY138 Ultrace, Longjumeau, France)으로 분석하였다. 각 원소의 표준용액은 $0,1,10$ $\mathrm{ppm}$ 의 농도로 조제하여 표준검량곡선을 작성하였으며 이 때, ICP-AES의 작동조건은 power: $1.0 \mathrm{KW}$ for aqueous, nebulizer pressure: 3.5 bar for meinhard type c, aerosol flow rate: $0.3 \mathrm{~L} / \mathrm{min}$, sheath gas flow: $0.3 \mathrm{~L} / \mathrm{min}$, cooling gas: $12 \mathrm{~L} / \mathrm{min}$ 이었다. 각 무기질의 검출 파장은 $\mathrm{Ca}: 393.366$, Mg: 279.553, Mn: 257.610, Se: 196.060, Na: 588.995, K: 766.491, Fe: 238.204, P: 213.618, Cu: 324.754 및 Zn: 213.856 $\mathrm{nm}$ 이었다.

\section{루틴 함량 분석}

루틴 함량 분석은 Zhao 등(15)의 방법을 응용하여 분석하 였다. 추출된 각 시료는 $0.45 \mu \mathrm{m}$ membrane filter로 여과하여 $\mathrm{HPLC}$ 에 $10 \mu \mathrm{L}$ 주입하였으며, HPLC 분석에 사용된 시약은 모두 HPLC grade를 사용하였다. 국내산 및 중국산 메밀 추출물의 분석에 사용된 지표성분 루틴은 Sigma(USA)에서 구입하였고, 루틴의 HPLC의 분석 조건은 Table 1 에 나타내 었다.

\section{통계분석}

모든 실험결과는 SAS 9.3(SAS Institute Inc., Cary, NC, USA) 프로그램을 이용하여 one-way ANOVA 분석 및 student t-test를 수행하였고 평균값의 통계적 유의성은 $\mathrm{p}<0.05$ 수준에서 검정하였다.

\section{결과 및 고찰}

\section{일반성분 분석}

국내산 메밀과 중국산 메밀의 일반성분은 Table 2 에 나타 내었다. 국내산 단메밀과 쓴메밀 $100 \mathrm{~g}$ 중에는 수분 9.8 , $8.8 \%$, 조회분 $2.9,2.2 \%$, 조지 방 $2.5,3.1 \%$, 조단백질 11.1 , $12.1 \%$, 탄수화물 $73.8,73.8 \%$ 로 유사하게 함유되어 있었다. 한편, 중국산 단메밀과 쓴메밀의 일반성분은 수분 13.4 , $12.7 \%$ 로 국내산 메밀의 수분 함량보다 약간 높게 나타났으 며, 탄수화물 함량은 $71.0,70.2 \%$ 로 국내산 메밀보다 낮았 다. 그러나, 나머지 조회분 $(1.8,2.6 \%)$, 조지방 $(2.9,3.2 \%)$, 조단백질(11.0, $11.3 \%)$ 은 국내산과 크게 차이를 보이지 않 았다. 이러한 결과는 Maeng 등(16)이 보고한 국내산 메밀의 일 반성분(수분: $9.7 \sim 12.7 \%$, 조회분: $1.9 ~ 2.3 \%$, 조지방: 2.3 2.4\%, 조단백질: 10.7 12.2\%)과 유사하게 나타났으며,
Table 1. HPLC conditions for the analysis of phenolic compounds

\begin{tabular}{|c|c|c|c|}
\hline Instrument & \multicolumn{3}{|c|}{ Conditions } \\
\hline Column & \multicolumn{3}{|c|}{ SunfireTM C18 $5.0 \mu \mathrm{m}, 4.6 \mathrm{~mm} \times 250 \mathrm{~mm}$} \\
\hline \multirow[t]{5}{*}{ Column temp. } & & $40^{\circ} \mathrm{C}$ & \\
\hline & Time (min) & Solvent $A^{1)}$ & Solvent $B^{2)}$ \\
\hline & 0 & 8 & 92 \\
\hline & 23 & 8 & 92 \\
\hline & 26 & 15 & 85 \\
\hline \multirow{5}{*}{$\begin{array}{l}\text { Mobile phase } \\
\text { (Gradient) }\end{array}$} & 36 & 30 & 70 \\
\hline & 40 & 45 & 55 \\
\hline & 43 & 45 & 55 \\
\hline & 45 & 8 & 92 \\
\hline & 53 & 8 & 92 \\
\hline Detector & \multicolumn{3}{|c|}{ Waters 996 Photodiode Array Detector $(280 \mathrm{~nm})$} \\
\hline Flow rate & \multicolumn{3}{|c|}{$1.0 \mathrm{~mL} / \mathrm{min}$} \\
\hline Injection volume & \multicolumn{3}{|c|}{$10 \mu \mathrm{L}$} \\
\hline Run time & \multicolumn{3}{|c|}{$53 \mathrm{~min}$} \\
\hline
\end{tabular}

${ }^{1)}$ Solvent A, Acetonitrile.

${ }^{2)}$ Solvent B, 0.5\% H3PO4-Water.

Lee 등(17)이 서술한 메밀의 영양성분(조회분: $2 ~ 5 \%$, 조지 방: $2 \%$, 조단백질: $13 \%$ )과도 유사한 결과를 보였다. 그러나, 중국산 단메밀 및 쓴메밀의 일반성분을 $\operatorname{Kim}$ 등(18)이 보고 한 중국산 단메밀 및 쓴메밀의 일반성분과 비교하면, 중국 산 단메밀의 조회분은 $1.8 \%$ 로 유사하였으나, 중국산 쓴메 밀의 조회분은 $1.9 \%$ 로 조금 낮게 나타났다. 또한, 조지방의 경우 단메밀 $1.3 \%$, 쓴메밀 $1.1 \%$ 로 본 연구결과 보다 낮았으 며, 조단백질 함량은 단메밀 $10.1 \%$, 쓴메밀 $9.2 \%$ 로 본 연구 결과보다 약간 낮았다. Shibata 등(19)에 의하면 메밀은 산 지에 따라 품질의 차이가 있으며, 일반적으로 북부 지방보 다는 남부지방의 메밀이 더 좋은 품질을 갖고 있다고 보고 하였다. 따라서, 이러한 연구 결과는 국내산 메밀의 경우 단메밀과 쓴메밀의 일반성분이 크게 차이가 나지 않으나, 중국산 메밀의 경우 남부지방 및 북부지방의 환경에 의하여 메밀의 일반성분들이 조금씩 차이가 난다고 예상된다.

Table 2. Proximate compositions of Korean and Chinese buckwheats

$(\%, \mathrm{w} / \mathrm{v})$

\begin{tabular}{cccccc}
\hline $\begin{array}{c}\text { Proximate } \\
\text { composition }\end{array}$ & Moisture & $\begin{array}{c}\text { Crude } \\
\text { protein }\end{array}$ & Crude fat & Crude ash Carbohydrate \\
\hline $\begin{array}{c}\text { common } \\
\text { buckwheat }\end{array}$ & $9.8 \pm 0.42$ & $11.1 \pm 0.34$ & $2.9 \pm 0.37$ & $2.5 \pm 0.03$ & $73.8 \pm 0.85$ \\
Korean $\begin{array}{c}\text { tartary } \\
\text { buckwheat } \\
\begin{array}{c}\text { common } \\
\text { buckwheat }\end{array}\end{array}$ & $8.8 \pm 0.10$ & $12.1 \pm 0.18$ & $3.1 \pm 0.05$ & $2.2 \pm 0.03$ & $73.8 \pm 0.20$ \\
Chinese $\begin{array}{c}\text { tartary } \\
\text { buckwheat }\end{array}$ & $12.7 \pm 0.29$ & $11.3 \pm 0.60$ & $3.2 \pm 0.39$ & $2.6 \pm 0.10$ & $70.2 \pm 1.11$ \\
\hline
\end{tabular}




\section{유리 아미노산 분석}

국내산 및 중국산 메밀에 함유된 유리 아미노산은 Table 3 에 나타난 바와 같이 총 16 종류로 분석되었다. 다양한 아미 노산 중에서는 glutamine이 국내산 단메밀 $2,612.1 \mathrm{mg}$, 국내 산 쓴메밀 $2,250.9 \mathrm{mg}$, 중국산 단메밀 $2,923.8 \mathrm{mg}$, 중국산 쓴메밀 2,996.1 mg으로 가장 높은 함량을 보였으며, aspartic acid, arginine 등이 $1,000 \mathrm{mg} / \mathrm{g} \mathrm{sample} \mathrm{이상으로} \mathrm{높은} \mathrm{함량을}$ 보였다. 그러나, 국내산 단메밀, 국내산 쓴메밀, 중국산 단 메밀, 중국산 쓴메밀의 지역별 및 품종별 간의 아미노산 조성 차이는 크게 나타나지 않았다. Woo 등(20)은 국내산 발아 메밀의 아미노산 조성은 단메밀에서 valine이 약 $40 \%$, tyrosine이 $28 \%$ 로 높은 함량을 보였으며, 국내산 발아 쓴메 밀에서는 valine이 약 $62 \%$ 함유되었으며, 메밀 줄기 및 뿌리 에서는 glutamine이 주요 아미노산이라고 보고하였다. 또 한, Lee 등(22)은 발아메밀이 발아 전 메밀보다 Valine, Threonine, Methionine, Isoleucine, Leucine, Phenylalanine, Lysine 등의 필수아미노산 함량이 더 높다고 보고하였다. 한편, 미국산 메밀의 아미노산 함량은 lysine이 가장 높게 나타났고, glutamic acid, proline의 함량은 낮게 나타났다고 보고되었다(21). 따라서, 이러한 연구결과는 메밀은 종자, 줄기 및 발아상태에 따라 다른 아미노산 조성을 나타내며, 특히, 자생지역(아시아, 미국 등)에 따른 아미노산 조성은 다르게 나타난다는 것을 의미한다.

Table 3. Free amino acid compositions of Korean and Chinese buckwheats

\begin{tabular}{lcccc}
\hline \multirow{2}{*}{ Amino acids } & \multicolumn{2}{c}{ Korean } & \multicolumn{2}{c}{ (mg/100 g samples). } \\
\cline { 2 - 5 } & $\begin{array}{c}\text { Common } \\
\text { buckwheat }\end{array}$ & $\begin{array}{c}\text { Tartary } \\
\text { buckwheat }\end{array}$ & $\begin{array}{c}\text { Common } \\
\text { buckwheat }\end{array}$ & $\begin{array}{c}\text { Tartary } \\
\text { buckwheat }\end{array}$ \\
\hline Aspartic acid & $1,198.1 \pm 6.36$ & $1,105.1 \pm 3.60$ & $1,306.9 \pm 16.32$ & $1,403.5 \pm 8.53$ \\
Threonine & $496.6 \pm 0.56$ & $449.3 \pm 1.02$ & $554.9 \pm 7.73$ & $578.4 \pm 8.27$ \\
Serine & $618.3 \pm 1.18$ & $568.9 \pm 3.79$ & $668.3 \pm 5.38$ & $720.9 \pm 12.10$ \\
Glutamine & $2,612.1 \pm 13.89$ & $2,250.9 \pm 2.24$ & $2,923.8 \pm 31.17$ & $2,996.1 \pm 78.87$ \\
Proline & $359.5 \pm 8.62$ & $322.3 \pm 9.92$ & $396.3 \pm 4.40$ & $408.2 \pm 11.77$ \\
Glycine & $748.9 \pm 4.18$ & $675.0 \pm 2.18$ & $852.0 \pm 8.92$ & $876.3 \pm 8.73$ \\
Alanine & $552.9 \pm 5.04$ & $503.9 \pm 1.62$ & $605.2 \pm 9.84$ & $638.9 \pm 4.54$ \\
Valine & $461.4 \pm 6.71$ & $487.9 \pm 2.56$ & $609.5 \pm 6.28$ & $684.2 \pm 13.98$ \\
Methionine & $152.9 \pm 7.62$ & $169.8 \pm 4.36$ & $202.2 \pm 8.45$ & $204.8 \pm 4.91$ \\
Isoleucine & $344.9 \pm 2.19$ & $379.8 \pm 2.20$ & $458.2 \pm 10.81$ & $546.2 \pm 4.42$ \\
Leucine & $790.7 \pm 5.35$ & $750.9 \pm 6.57$ & $912.9 \pm 23.68$ & $979.9 \pm 4.51$ \\
Tyrosine & $287.2 \pm 16.54$ & $292.2 \pm 6.92$ & $354.1 \pm 13.57$ & $416.7 \pm 9.08$ \\
Phenylalanine & $568.8 \pm 2.23$ & $533.0 \pm 2.99$ & $664.9 \pm 3.85$ & $718.7 \pm 5.39$ \\
Lysine & $727.3 \pm 7.31$ & $669.1 \pm 1.51$ & $803.1 \pm 12.07$ & $807.0 \pm 8.68$ \\
Histidine & $268.3 \pm 4.63$ & $264.1 \pm 1.32$ & $313.9 \pm 4.46$ & $359.2 \pm 1.20$ \\
Arginine & $1,061.0 \pm 13.15$ & $932.5 \pm 8.70$ & $1,267.8 \pm 30.09$ & $1,388.6 \pm 1.11$ \\
\hline & & & &
\end{tabular}

\section{미네랄 분석}

국내산 및 중국산 메밀에 함유된 미네랄 함량은 Table 4에 나타내었다. 국내산 메밀 및 중국산 메밀의 미네랄 함량 은 K(국내산 단메밀: $461 \mathrm{mg}$, 국내산 쓴메밀: $423 \mathrm{mg}$, 중국 산 단메밀: $569 \mathrm{mg}$, 중국산 쓴메밀: $498 \mathrm{mg}$ )의 함량이 가장 높게 나타났다. 특히, 국내산 단메밀 및 쓴메밀 보다는 중국 산 단메밀 및 쓴메밀에서 $\mathrm{K}$ 의 함량이 더 높았으며, 단메밀 이 쓴메밀에 비하여 높은 $\mathrm{K}$ 함량을 보였다. 그 다음으로는 $\mathrm{P}$ 및 $\mathrm{Mg}$ 의 함량이 높게 나타났는데, 역시 국내산 단메밀(P: $364.6 \mathrm{mg}, \mathrm{Mg}: 203.8 \mathrm{mg}$ ) 및 쓴메밀(P: $328.6 \mathrm{mg}, \mathrm{Mg}: 181.8$ $\mathrm{mg}$ ) 보다는 중국산 단메밀 $(\mathrm{P}: 555.0 \mathrm{mg}, \mathrm{Mg}: 255.9 \mathrm{mg}$ ) 및 쓴메밀(P: $451.8 \mathrm{mg}, \mathrm{Mg}: 234.2 \mathrm{mg}$ )에서 높게 나타났으 며, 단메밀이 쓴메밀보다는 높은 $\mathrm{P}$ 및 $\mathrm{Mg}$ 함량을 보였다. 한편, $\mathrm{Cu}, \mathrm{Mn}, \mathrm{Na}, \mathrm{Zn}$ 등의 미네랄은 국내산 메밀 및 중국산 메밀에서 $10 \mathrm{mg} / 100 \mathrm{~g}$ sample로 미량으로 함유되어 있었다. 미네랄 분석에서 특이한 점은, 국내산 쓴메밀의 $\mathrm{Ca}(60.5$ $\mathrm{mg})$ 및 $\mathrm{Fe}(27.9 \mathrm{mg})$ 함량이 국내산 단메밀 $(38.9,5.3 \mathrm{mg})$, 중국산 단메밀 $(38.4,5.5 \mathrm{mg})$, 중국산 쓴메밀 $(34.1,8.8 \mathrm{mg})$ 과 비교하여 유의적으로 높은 값을 보였다. Shim 등(23)에 의 하면 국내산 메밀 및 중국산 메밀은 품종에 따라 다른 무기 질 함량을 보였는데, 본 연구에서 국내산 단메밀의 높은 $\mathrm{Ca}$ 및 $\mathrm{Fe}$ 함량은 품종의 차이에 의한 것으로 사료된다. 하지만, 이러한 결과는 향후 추가 연구가 필요하다고 예상 된다. 본 연구에서 분석된 메밀의 미네랄 함량을 다른 연구 들과 비교하면, $\operatorname{Kim}$ 등(18)이 보고한 중국산 단메밀 및 쓴메 밀의 미네랄 성분 중 $\mathrm{P}$ 와 $\mathrm{Mg}$ 가 주요 미네랄이며, 다른 미네 랄보다 높은 함유량을 보인다는 연구결과와 일치한다. 따 라서, 본 연구의 결과에 의하면, 메밀의 주요 미네랄 $(\mathrm{P}, \mathrm{Mg}$, $\mathrm{K})$ 은 쓴메밀보다는 단메밀에 높게 함유되어 있으며, 국내 산보다는 중국산에 더 많이 함유되어 있는 것으로 분석되었 다.

Table 4. Mineral contents of Korean and Chinese buckwheats

\begin{tabular}{ccccc} 
& \multicolumn{2}{c}{ Korean } & \multicolumn{2}{c}{ Chinese } \\
\hline \multirow{2}{*}{ Minerals 100 g samples) }
\end{tabular}




\section{주요 지방산 분석}

국내산 메밀 및 중국산 메밀에 함유되어 있는 지방산 함량은 Table 5에 나타내었다. 포화지방산 중에서는 palmitic acid가 약 14.2 16.1\%를 보이면서 가장 높은 포화 지방산 함량을 보였으며, stearic acid가 1.9 2.3\%로 두 번째 로 높은 함량을 보였다. 특히, palmitic acid는 국내산 $(15.6 \%)$ 및 중국산 단메밀(16.1\%)에서 국내산(14.2\%) 및 중국산 쓴 메밀(14.1\%) 보다 높은 함량을 보였으며, 국내산과 중국산 과의 차이는 크게 보이지 않았다. 그 외 다른 포화지방산 myristic acid, arachidonic acid, behenic acid, lignoceric acid 는 모두 $2 \%$ 이하의 낮은 함유량을 보였다. 한편, 불포화지 방산은 oleic acid와 linoleic acid의 함량이 다른 불포화지방 산보다 높게 나타났는데, oleic acid는 국내산 메밀 (39.5 40.8\%)과 중국산 메밀(37.0 38.5\%)의 차이는 크게 보이지 않았으며, 단메밀과 쓴메밀의 차이도 보이지 않았 다. 그러나, linoleic acid 함량은 중국산 쓴메밀이 $38.6 \%$ 를 보이면서, 국내산 단메밀(31.7\%), 국내산 쓴메밀(33.9\%), 중국산 단메밀(32.9\%) 보다 높은 함유량을 보였다. 그 외 다른 불포화지방산 palmitoleic acid, linolenic acid, eicosenoic acid, eicosadienoic acid, eicosatetraenoic acid는 모두 $3.5 \%$ 이하의 낮은 함유량을 보였다. 따라서, 본 연구의 결과, 국내산 및 중국산 메밀의 주요 지방산은 포화지방산 인 palmitic acid와 불포화지방산인 oleic acid, linoleic acid로 밝혀졌다. 특히 불포화지방산인 linoleic acid는 polyunsaturated omega-6 fatty acid 라고도 불리며, 혈압강하, 혈중 콜레스테 롤 수치 등을 낮추는 효과가 있는 것으로 알려져 있다(24). 따라서, 국내산 및 중국산 단메밀과 쓴메밀은 풍부한 불포화 지방산의 함유로 다양한 기능성이 나타날 것으로 기대된다.

Table 5. Saturated and unsaturated fatty acid contents of Korean and Chinese buckwheats

\begin{tabular}{|c|c|c|c|c|c|}
\hline \multirow{2}{*}{\multicolumn{2}{|c|}{$\begin{array}{c}\text { Fatty acid } \\
\text { (\% of } 100 \mathrm{~g} \text { samples) }\end{array}$}} & \multicolumn{2}{|c|}{ Korean } & \multicolumn{2}{|c|}{ Chinese } \\
\hline & & $\begin{array}{c}\text { Common } \\
\text { buckwheat }\end{array}$ & $\begin{array}{c}\text { Tartary } \\
\text { buckwheat }\end{array}$ & $\begin{array}{c}\text { Common } \\
\text { buckwheat }\end{array}$ & $\begin{array}{c}\text { Tartary } \\
\text { buckwheat }\end{array}$ \\
\hline \multirow{6}{*}{$\begin{array}{c}\text { Saturated } \\
\text { fatty acids }\end{array}$} & C14:0 Myristic acid & 0.1 & 0.1 & 0.1 & 0.1 \\
\hline & C16:0 Palmitic acid & 15.6 & 14.2 & 16.1 & 14.1 \\
\hline & C18:0 Stearic acid & 2.1 & 2.3 & 2.0 & 1.9 \\
\hline & C20:0 Arachidonic acid & 1.8 & 1.5 & 1.6 & 1.3 \\
\hline & C22:0 Behenic acid & 1.9 & 1.5 & 1.8 & 1.4 \\
\hline & C24:0 Lignoceric acid & 1.2 & 0.7 & 1.1 & 0.8 \\
\hline \multirow{7}{*}{$\begin{array}{l}\text { Unsaturated } \\
\text { fatty acids }\end{array}$} & C16:1 Palmitoleic acid & 0.2 & 0.2 & 0.2 & 0.2 \\
\hline & C18:1 Oleic acid & 39.5 & 40.8 & 38.5 & 37.0 \\
\hline & C18:2 Linoleic acid & 31.7 & 33.9 & 32.9 & 38.6 \\
\hline & C18:3 Linolenic acid & 1.7 & 1.1 & 2.0 & 1.2 \\
\hline & C20:1 Eicosenoic acid & 3.3 & 2.4 & 3.0 & 2.2 \\
\hline & C20:2 Eicosadienoic acid & 0.2 & 0.2 & 0.2 & 0.3 \\
\hline & C20:3 Eicosatetraenoic acid & 0.1 & 0.1 & 0.1 & 0.1 \\
\hline
\end{tabular}
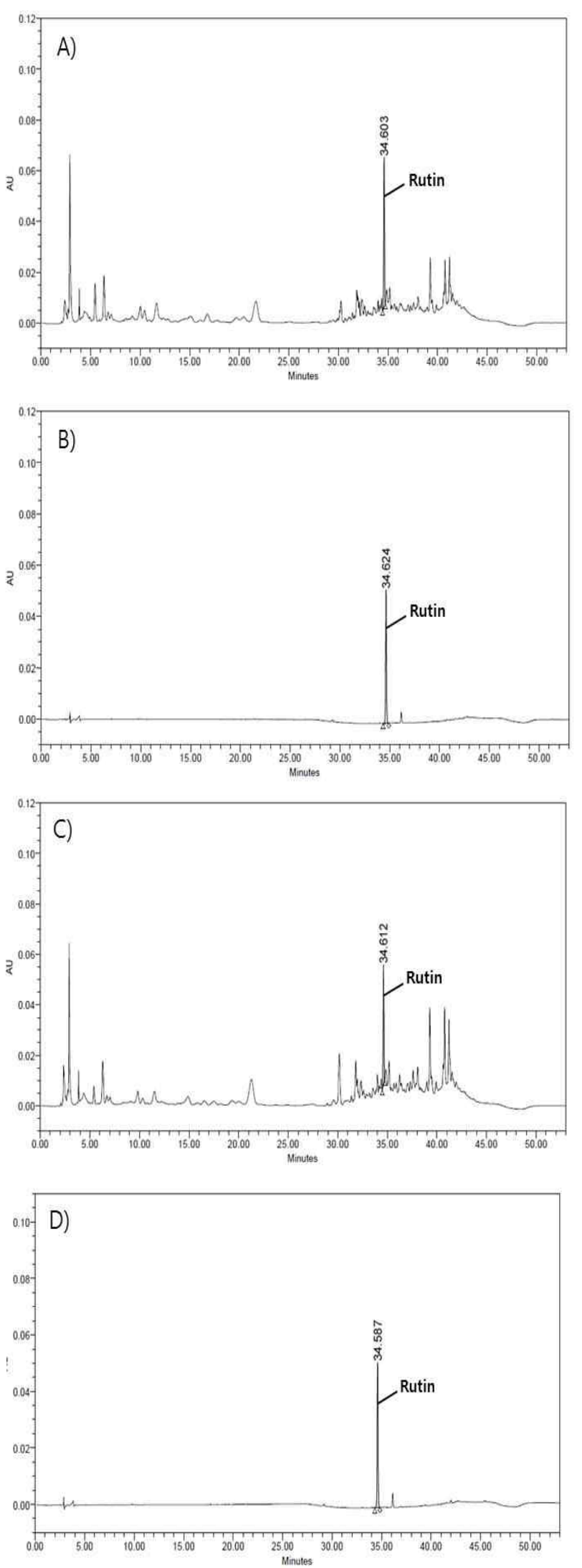

Fig. 1. HPLC chromatograms of Korean and Chinese buckwheats.

A, Korean common buckwheat; B, Korean tartary buckwheat; C, Chinese common buckwheat; D, Chinese tartary buckwheat. 

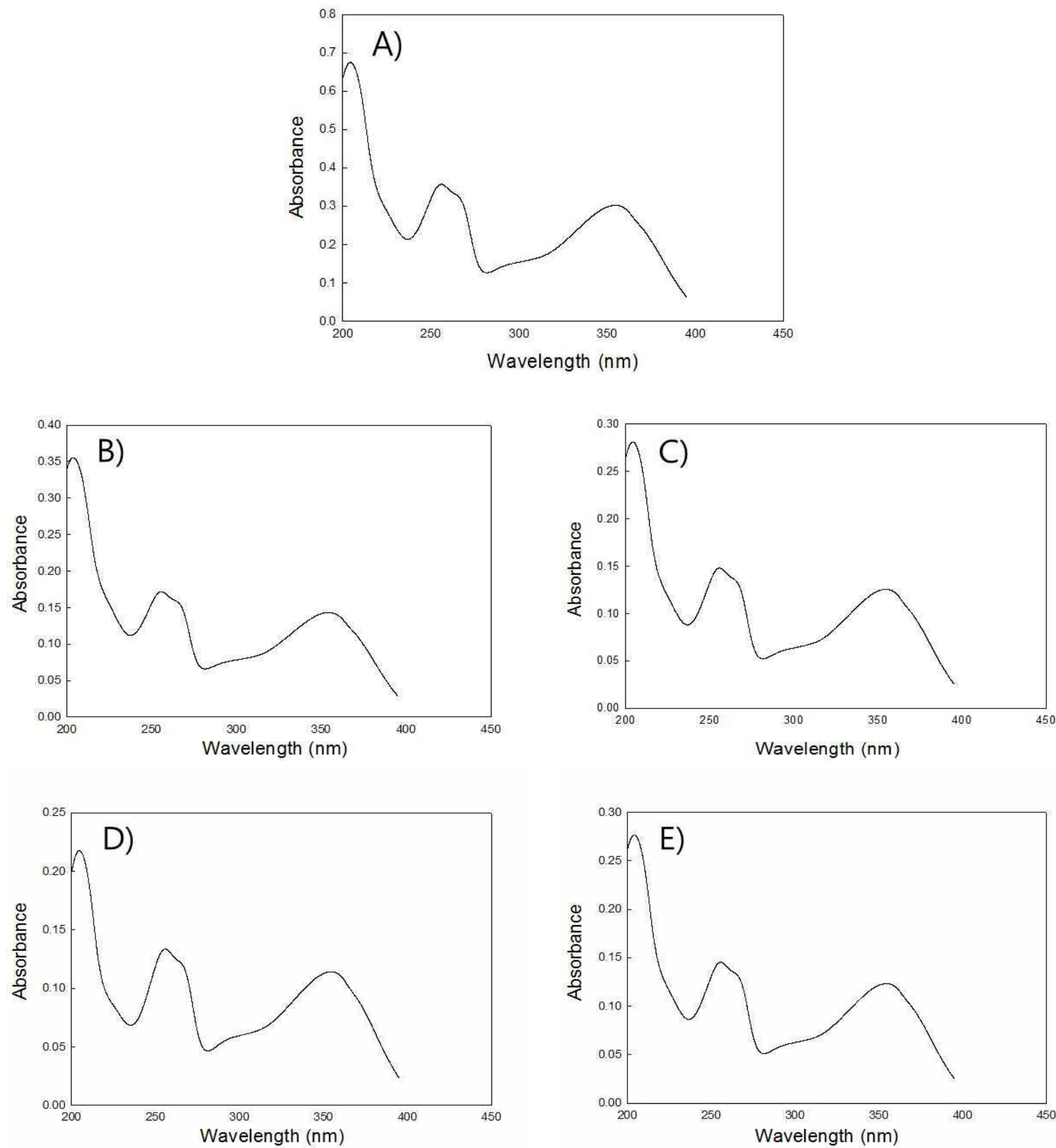

Fig. 2. UV spectrum of rutin standard and rutin peaks isolated from Korean and Chinese buckwheats.

A, Rutin standard; B, Korean common buckwheat; C, Korean tartary buckwheat; D, Chinese common buckwheat; E, Chinese tartary buckwheat.

\section{루틴함량 분석}

루틴은 메밀의 주요 구성성분 중 하나로 동맥경화, 뇌출 혈 및 고혈압의 예방과 치료, 항산화 효과 등의 다양한 생리 활성을 가지고 있다(2). 따라서, 본 연구에서는 국내산 및 중국산의 단메밀과 쓴메밀의 루틴 함량을 분석하였다(Fig. 1, Table 6). 국내산 단메밀(Fig. 1A)과 중국산 단메밀(Fig. $1 C)$ 에 함유된 루틴은 34.6 분에 검출되었다. 또한, 국내산
쓴메밀(Fig. 1B)과 중국산 쓴메밀(Fig. 1D)에 함유된 루틴 역시 34.6분에 검출되었으며, 쓴메밀의 경우 루틴 외의 다 른 peak는 거의 검출되지 않았다. 따라서, 국내산 메밀 및 중국산 메밀의 주요 phenolic compound는 루틴으로 확인 되었으며, 특히 국내산 및 중국산 쓴메밀의 경우 루틴이외 의 다른 phenolic compound는 거의 없었다. HPLC의 peak area를 기준으로 루틴 함량을 계산한 결과, Table 6와 같이 
국내산 단메밀과 중국산 단메밀은 각각 $5.7,4.4 \mathrm{mg}$ 으로 함유되어 있었고, 국내산 및 중국산 쓴메밀에는 각각 265.0, $261.0 \mathrm{mg}$ 의 루틴이 함유되어 있었다. Morishita 등(25)의 연구에 따르면, 일본산 메밀의 루틴 함량은 단메밀이 12.2 $\mathrm{mg}$ 으로 본 연구보다 높게 나타났으며, 쓴메밀 역시 $1,808.7$ $\mathrm{mg}$ 으로 본 연구 결과보다 높은 값을 보였다. 한편, 국내산 메밀 및 중국산 메밀에서 추출된 루틴의 확인은 spectrophotometer로 하였다. Fig. 2에서는 루틴 standard 및 국내산 메밀 및 중국산 메밀에서 추출된 34.6분 peak의 UV spectrum을 보여준다. 루틴 표준물질은 $354 \mathrm{~nm}$ 에서 최대 흡광도를 보이면서, Maeng 등(16)이 보고한 루틴의 최대흡 광도 $(354 \mathrm{~nm})$ 와 UV spectrum pattern이 일치하였다. 또한, 국내산 메밀 및 중국산 메밀에서 분리된 34.6분 peak의 UV spectrum 역시 루틴 standard와 동일한 경향을 보였으며, $354 \mathrm{~nm}$ 에서 최대 흡광도를 보였다(Fig. 2). Park 등(2)에 따르면 쓴메밀의 루틴 함량 $(2,042 \mathrm{mg} / 100 \mathrm{~g})$ 은 단메밀의 루틴 함량 $(12.8 \mathrm{mg} / 100 \mathrm{~g})$ 보다 높았다. 한편, 다른 나라에서 수집한 메밀의 루틴 함량을 살펴보면, Park 등(26)이 중국, 인도, 부탄 등 7 개 아시아 국가에서 수집된 쓴메밀 50종의 루틴 함량을 분석하였는데, 부탄에서 수집된 메밀의 루틴 함량 $(2,139 \mathrm{mg} / 100 \mathrm{~g})$ 이 다른 나라에서 수집된 메밀의 루틴 함량 $(1,199 \sim 1,938 \mathrm{mg} / 100 \mathrm{~g})$ 보다 높게 나타났다. 따라서, 메밀의 루틴 함량은 품종별 및 재배 지역별로 차이가 나는 것으로 사료된다.

Table 6. Rutin contents of Korean and Chinese buckwheats

\begin{tabular}{ccccc} 
& & & & (mg/g sample) \\
\hline \multirow{2}{*}{ Buckwheats } & \multicolumn{2}{c}{ Korean } & \multicolumn{2}{c}{ Chinese } \\
\cline { 2 - 5 } & $\begin{array}{c}\text { Common } \\
\text { buckwheat }\end{array}$ & $\begin{array}{c}\text { Tartary } \\
\text { buckwheat }\end{array}$ & $\begin{array}{c}\text { Common } \\
\text { buckwheat }\end{array}$ & $\begin{array}{c}\text { Tartary } \\
\text { buckwheat }\end{array}$ \\
\hline rutin & $5.7 \pm 0.01$ & $265.0 \pm 0.28$ & $4.4 \pm 0.03$ & $261.0 \pm 0.67$ \\
\hline
\end{tabular}

\section{요 약}

본 연구는 국내산 및 중국산 단메밀과 쓴메밀의 일반성 분, 아미노산 조성, 지방산 조성과 루틴 함량을 분석하였다. 다양한 메밀의 수분, 조단백질, 조지방, 조회분, 탄수화물의 함량은 각각 8.78 13.37, 11.00 12.11, 2.87 3.18, 1.80 2.58, $70.2 \sim 73.8 \%$ 로 분석되었다. 국내산 및 중국산 메밀의 주요 아미노산은 aspartic acid(1,105.1 1,403.5mg\%), glutamine (2,250.9 2,996.1 mg\%), arginine(932.5 1,388.6 mg\%)로 분 석되었으며, $\mathrm{K}(423.7 \sim 569.4 \mathrm{mg} \%), \mathrm{Mg}(181.8 \sim 255.9 \mathrm{mg} \%)$, $\mathrm{P}(328.6 \sim 555.0 \mathrm{mg} \%)$ 가 주요 미네랄로 분석되었다. 한편, 지방산 조성은 포화지방산인 palmitic acid(14.2 16.1\%)와 불포화 지방산인 oleic $\operatorname{acid}(37.0 ~ 40.8 \%)$, linoleic acid (31.7 38.6\%)가 주요 지방산으로 분석되었다. 또한, 국내산
및 중국산 메밀의 주요 phenolic compound는 루틴으로 분석 되었으며, 쓴메밀 $(261.0 ~ 265.0 \mathrm{mg} / \mathrm{g})$ 이 단메밀(4.39 5.68 $\mathrm{mg} / \mathrm{g}$ )보다 높은 함량을 보였다. 본 연구를 종합하면, 국내산 단메밀은 중국산 단메밀과 비교하여 영양성분은 크게 차이 를 보이지 않았으나, 메밀의 주요 활성성분인 루틴은 약간 높게 함유되어 있었다. 또한 국내산 쓴메밀은 중국산 쓴메 밀에 비하여 $\mathrm{Ca}, \mathrm{Fe}$ 함량이 높았으며, 루틴 역시 약간 높은 함유량을 보였다. 따라서, 메밀에서 주요 활성성분으로 제 시되고 있는 루틴의 함량이 중국산 메밀보다 국내산 메밀에 높게 함유되어 있기 때문에 국내산 메밀에서 더 높은 생리 활성이 나타날 것으로 기대된다.

\section{References}

1. Durkee AB (1977) Polyphenols of the bran-aleurone fraction of buckwheat weed (Fagopyrum sagitatum Gilib). J Agric Food Chem, 25, 286-287

2. Park BJ, Kwon SM, Park JI, Chang KJ, Park CH (2005) Phenolic compounds in common and tartary buckwheat. Korean J Crop Sci, 50, 175-180

3. Tsurunaga Y, Takahashi T, Katsube T, Kudo A, Kuramitsu O, Ishiwata M, Matsumoto S (2013) Effects of UV-B irradiation on the levels of anthocyanin, rutin and radical scavenging activity of buckwheat sprouts. Food Chem, 141, 552-556

4. Lee CC, Shen SR, Lai YJ, Wu SC (2013) Rutin and quercetin, bioactive compounds from tartary buckwheat, prevent liver inflammatory injury. Food Funct, 4, 794-802

5. Rhee SK (2008) Bioactive function and application techniques of process in buckwheat. Food J, 134, 76-79

6. Gulpinar AR, Orhan IE, Kan A, Senol FS, Celik SA, Kartal M (2012) Estimation of in vitro neuroprotective properties and quantification of rutin and fatty acids in buckwheat (Fagopyrum esculentum Moench) cultivated in Turkey. Food Res Int, 46, 536-543

7. Choi JY, Lee JM, Lee DG, Cho SH, Yoon YH, Cho EJ, Lee SH (2015) The n-butanol fraction and rutin from tartary buckwheat improve cognition and memory in an in vivo model of amyloid- $\beta$-induced alzheimer's disease. J Med Food, 18, 631-641

8. Yoon BR, Cho BJ, Lee HK, Kim DJ, Rhee SK, Hong HD, Kim KT, Cho CW, Choi HS, Lee BY, Lee OH (2012) Antioxidant and anti-adipogenic effects of ethanolic extracts from tartary and common buckwheats. Korean J Food Preserv, 19, 123-130

9. Tsai H, Deng H, Tsai S, Hsu Y (2012) Bioactivity 
comparison of extracts from various parts of common and tartary buckwheat: evaluation of the antioxidant and angiotensin-converting enzyme inhibitory activities. Chem Cent J, 6, 78

10. Bonafaccia G, Gambelli L, Fabjan N, Kreft I (2003) Trace elements in flour and bran from common and tartary buckwheat. Food Chem, 83, 1-5

11. AOAC (1990) Official Methods of Analysis. 15th ed. Association of Official Analytical Chemists, Washington DC, USA

12. Waters AccQ-Tag (1993) Amino acid Analysis System. Operator's Manual

13. AOAC (1995) Official Methods of Analysis. 16th ed. The scientific association dedicated to analytical excellence. Washington DC, USA, p 11-15

14. AOAC (1995) Official Methods of Analysis. 16th ed. The scientific association dedicated to analytical excellence. Washington DC, USA, p 71-73

15. Zhao G, Peng LX, Wang S, Hu YB, Zou L (2012) HPLC fingerprint-antioxidant properties study of buckwheat. J Int Agric, 11, 1111-1118

16. Maeng YS, Park HK, Kwon TB (1990) Analysis of rutin contents in buckwheat and buckwheat foods. Korean J Food Sci Technol, 22, 732-737

17. Lee SY, Shim HH, Ham SS, Rhee HI, Choi YS, Oh SY (1991) The nutritional components of buckwheat flours and physicochemical properties of freeze-dried buckwheat noodles. J Korean Soc Food Nutr, 20, 354-362

18. Kim JK, Kim SK (2005) Compositions and pasting properties of Fagopyrum esculentum and Fagopyrum tartaricum Endosperm flour. Korean J Food Sci Technol, 37, 149-153

19. Shibata S, Imai T, Chikubu S, Miyahara T (1979) The composition of buckwheat flour of various varieties and cultivated at various periods. Rept Natl Food Res Inst, $34,1-7$

20. Woo SH, Kamal AHM, Park SM, Kwon SO, Park SU, Roy SK, Lee JY, Choi JS (2013) Relative distribution of free amino acids in buckwheat. Food Sci Biotechnol, 22, 665-669

21. Pomeranz Y, Robbins GS (1972) Amino acid composition of buckwheat. J Agric Food Chem, 20, 270-274

22. Lee EH, Kim CJ (2008) Nutritional changes of buckwheat during germination. Koean J Food Culture, 23, 121-129

23. Shim TH, Lee HH, Lee SY, Choi YS (1998) Composition of buckwheat (Fagopyrum esculentum Moench) cultivars from Korea. Korean J Food Sci Technol, 30, 1259-1266

24. Han CK, Lee BH, Song KS, Lee NH, Yoon CS (1996) Effects of antihypertensive diets mainly consisting of buckwheat, potato, and perilla seed on blood pressures and plasma lipids in normotensive and spontaneously hypertensive rats. J Nutr Health, 29, 1087-1095

25. Morishita T, Yamaguchi H, Degi K (2007) The contribution of polyphenols to antioxidative activity in common buckwheat and tartary buckwheat grain. Plant Prod Sci, 10, 99-104

26. Park BJ, Park JI, Chang KJ, Park CH (2005) Comparison in rutin content of tartary buckwheat (Fagopyrum tataricum). Korean J Plant Res, 18, 246-250 